\title{
Osaisinpa kirjoittaa!
}

Lovio, Maisa, Kirjoittajan yliopistot. Tutkimus kirjoittajakoulutuksesta Suomessa. Valtion taidehallinnon julkaisuja no 32 . Helsinki 1987.

Maisa Lovio on valtion kirjallisuustoimikunnan toimesta kartoittanut kirjoittajakoulutuksen järjestämistä, osanottoa ja tavoitteita. Aineisto on pääasiassa vuosilta 1984-85.

Tutkija on piirtänyt karttaa opetussuunnitelmien, kurssiluettelojen, opinto-oppaiden ja esitteiden perusteella. Lisäksi on lähetetty kysely 432 Oriveden Opiston Topelius-Akatemian tai Suomen Nuoriso-opiston Kirjoittajaopiston kurssilla olleelle kirjoittajalle. 199 lomaketta tuli täytettynä takaisin. Oriveden Opistosta on saatu kurssilaisista myös matrikkelitietoja. Haastateltavana on ollut eri yhteisöjen edustajia, kurssien järjestäjiä ja opettajia, yhteensä 18. Ainoastaan kolme heistä on itse kirjailijaa ja yleensä jäädäänkin näin hallinnon näkökulmaan. Jotkut haastatellut vain ilmoittavat, ettei heidän yhteisönsä järjestä kirjoittajakoulutusta.

Kuvaan mahtuvat siis kansanopistot, kansalais- ja työväenopistot, opintokeskukset, kesäyliopistot, Pekkas-Akatemia, Nuoren Voiman liitto, Kansanvalistusseuran Kirjeopisto ja Yleisradio sekä valtakunnallisia ja alueellisia kirjailijaja kirjoittajajärjestöjä ja läänintaiteilijoita. Maisa Lovio kertoo myös koulujen ja korkeakoulujen antamasta opetuksesta. Varsinkin näiden kohdalla on ollut vaikeaa vetää selvityksen rajoja. Kirjoittamisen opetus lomittuu $\mathrm{mm}$. kirjallisuuden ja sen historian, suullisen viestinnän ja ainakin kouluissa kielentuntemuksenkin kanssa. Vaikka Lovio ilmoittaa kansanopistojen kohdalla jättävänsä pois asiatekstien ja lehtitekstien kurssit, hän korkeakouluihin päästyään kertoo mm. yleisistä kirjallisen viestinnän kursseista ja mainitsee myöhemmin esim. kustannustoimittajien kielenhuoltoseminaarit.

Rajankäynnin vaikeudet eivät ole Lovion syy, aineet ja asiat ovat kietoutuneet toisiinsa. Lovion työ kuitenkin johtaa kysymään joitakin käsitteitä ja niiden kattamia asioita. Tiedekorkeakoulujen kohdalla
Lovio sanoo, että varsinaisen luovan kirjoittamisen opetus puuttuu koulutuksesta tyystin. Toistakymmentä vuotta on ollut muotia puhua luovasta toiminnasta. Mikäpä siinä, onhan niitä rumempiakin sanoja, mutta itse käsite on mystisen epäselvä. Onko esim. kirjoittamisessa luomista vain runojen, taideproosan ja draaman kirjoittaminen? Miten perusteltua on sivuuttaa ja syrjiäkin asiatekstejä? Minä luen paljon mieluummin taitavasti kirjoitettua artikkelia kuin keskinkertaisia runoja.

Vaikka Lovio ei siis sen perusteellisemmin käsittele tieto- ja asiakirjoittamisen opetusta, hänkin toteaa yhteenvedoissaan, että tässä kohdassa on selvä koulutuksellinen tyhjiö. Kiitokset aiheellisesta huomautuksesta! Sitten kun keskustelussa edetään sisältöihinkin, joihin Lovio ei yritäkään kajota, on lähdettävä turhan ahtaista karsinoista.

Päätelmissään koulutuksen järjestämisestä Lovio laskee määrän ja tasonkin nousseen, mutta valittaa mm. nuorten kirjailijain jatkokoulutúksen ja kirjallisuuslukioiden puuttumista, kirjoittajakoulutuksen hajanaisuutta, pätevien ohjaajien riittämättömyyttä ja tutkimustiedon vähäisyyttä. Huokauksiin on aihetta. (Lähes huvittavana yksityiskohtana kerrottakoon, että kun taannoin yritettiin järjestelmällistä keskustelua muutamien koulutusta tarjoavien yhteisöjen kesken, ei opetusministeriöllä ollut momenttia maksaa ulkopuolisen sihteerin pikkuruisia matkakuluja ja vaivanpalkkoja.)

Toisia epäkohtia voitaneen parantaa paneutumalla päättäväisesti asioihin, mutta esim. nuorten kirjailijoiden jatkokoulutuksen ongelmassa tulevat vastaan myös epävarmuus tällaisen koulutuksen mahdollisuuksista sekä kustantajien sinänsä luvalliset talokohtaiset intressit. Aikuiskasvatuksen kentällä on aihetta ja varaa parantaa ohjaajien koulutusta ja parantamisen varaa on toki yhteistyössäkin, mutta samaan aikaan on myös tavoitteista keskusteltava realistisesti. Toiset asiantuntijat katsovat, että koulutuksella on rajansa, jotka tulevat vastaan nimenomaan lahjakkaimpien kohdalla.
Mystifioimatta kirjoittajakoulutusta kannattaa nämäkin varaukset ja varoitukset ottaa tosissaan.

Ne valitukset ja toivomukset, joita Maisa Lovio on kartoituksessaan kuullut kirjoittajilta, viittaavat oikeastaan samaan suuntaan kuin muutamat kokeneet kustantajat: hyödyllisimmäksi työskentelytavaksi arvioidaan henkilökohtainen ohjaus ja pahimmaksi epäkohdaksi sen riittämättömyys. Miten paljon voidaan hankkia oppaita, jotka pystyvät lahjakkaimpienkin hedelmälliseen kouluttamiseen, ja miten pitkälle tällainen opas pystyy kulkemaan? Sisältävätkö harrastajakirjoittajien toiveiden tynnyrit toisenlaisia unelmia kuin amatööriteatterin ja musiikin harrastajien? Entä jos nuoren kirjoittajan mahdollisuudet ovat erilaiset kuin sen keski-ikäisen, joka jo on vakiintunut kirjoittamisessakin — onko tämä otettava huomioon jo ohjausta organisoitaessa? Tavoitekeskustelua tarvitaan.

Maisa Lovio valaisee myös kirjoittajien yhteiskunnallista ja koulutustaustaa ja ikäryhmiä. Suuri osa kuuluu ammattinsa puolesta ylempiin sosiaaliryhmiin ja monilla on muitakin harrastuksia. Naisia ja keski-ikäisiä on paljon. Maisa Lovion suhteellisen suppeaan selvitykseen ei ole kuulunut verrata kirjoittajia esim. kuvataiteen, musiikin tai teatterityön harrastajiin. Mutta ne piirteet, joita Lovio paljastaa kirjoittajista, ovat enimmäkseen samoja, joita monet tutkimukset ovat osoittaneet taiteiden vakioystävistä. Motiiveista Lovio kertoo valitettavan vähän.

Naisten vastauksista Lovio toteaa, "kuinka vaikeata heidän on mikäli heidän elämänsä kulkee perinteisiä latuja — saada aikaa ja rauhaa, jotta voisivat kirjoittaa ja kehittyä siinä. Miesten kirjoittamista eivät sukupuolirooliodotukset sen sijaan näytä samalla tavalla haittaavan." Tunteeko joku piston sydämessään? Minkä verran naisilla on sanottavaa, joka jää sanomatta?

Jos kirjoittajain ohjausta halutaan edistää myös selvityksin ja tutkimuksin, on Lovion kirjasta jatkettava sisältökysymyksiin.

Aarne Laurila 